\title{
Impact of Bentonite Mining on Selecting Arthropods
}

\author{
CAROLYN HULL SIEG, DANIEL W. URESK, AND RICHARD M. HANSEN
}

\section{Abstract}

Arthropods were sampled in pitfall traps for 2 yr on bentonite mine spoils and adjacent, unmined big sagebrush (Artemisia tridentata) grasslands in southeastern Montana to assess the impacts of bentonite mining on selected arthropods, evaluate the success of early reclamation efforts in restoring arthropods to mined sites, and to identify limiting factors for colonization of spoils by arthropods. The most significant impacts on selected arthropods were on old, unreclaimed bentonite mine spoils, where after nearly $30 \mathrm{yr}$, numbers of 7 arthropod groups remained lower than on unmined sagebrush grasslands. Spoils covered with topsoil had higher captures of ground beetles (Carabidae) and crickets (Gryllidae) than unreclaimed spoils. And spoils covered with topsoil and seeded supported captures of most arachnids, Coleoptera, Hemiptera, and Formicidae similar to those on unmined sagebrush grasslands. Vegetative parameters measured in this study accounted for a portion of the variability in arthropod captures; however, microarthropod populations, arthropod vagility, and soil water contents may influence repopulation of mine spoils by some arthropods.

Key words: insects, reclamation, Coleoptera, Orthoptera, vegetation, mining reclamation

Information on arthropod colonization of mine spoils is important in view of their role in soil formation and other functions. A viable soil invertebrate community may be a prerequisite for a soil medium capable of sustaining acceptable plant growth on coal mine spoils (Ettershank et al. 1978). Insect activities (soil aeration, litter decomposition, nutrient cycling, pollination, seed distribution, etc.) and the effect of their dead bodies on new coal mine spoils may influence ecological succession more than the scattered plants (Smith 1928). Arthropods provide food for many species of vertebrates, thus enhancing the attractiveness of disturbed sites for colonizing vertebrates. The return of arthropods to mined areas is influenced by a variety of factors, including plant cover, species richness (Majer et al. 1984), and litter cover (Majer et al. 1982). Insect vagility (Neumann 1973), microarthropod populations, and other factors further influence arthropod repopulation of disturbed sites. The purpose of this study was to: (1) assess the impact of bentonite mining on selected arthropods, (2) evaluate the success of reclamation in restoring these arthropods to mine spoils, and (3) identify limiting factors for arthropod colonization of bentonite mine spoils.

\section{Study Area}

This study was conducted $9 \mathrm{~km}$ west of Alzada, in Carter County, Montana. Elevations range from 1,000 to $1,100 \mathrm{~m}$. A big sagebrusin (Artemisia tridentata)/ buffalograss (Buchloe dactyloides) community occupied the majority of the study area (MacCracken et al. 1983). Small $(<5$ ha) bentonite mine spoil piles and pits were scattered throughout the study area. Average annual precipitation for the area is $37 \mathrm{~cm}$, of which nearly $50 \%(18 \mathrm{~cm})$ occurs between May and July (National Oceanic and Atmospheric Administration

\footnotetext{
Sieg and Uresk are Wildlife Biologist and Research Biologist, respectively, Rocky Mountain Forest and Range Experiment Station, Rapid City, South Dakuta, in cooperation with the South Dakota School of Mines and Technology. Station headquarters is in Fort Collins, in cooperation with Colorado State University. Hansen is Professor, Department of Range Science, Colorado State University, Fort Collins.

Appreciation is extended to Lynn Alexander, Colorado State University, for help with field work and to Raquel Peña Neira for identifying the arthropods. The Wyotana Ranch provided a place to park a trailer used as the field work headquarters. N.L. Ba roid, Inc., and International Minerals Corporation granted permission to use their land.

Manuscript accepted 14 July 1986.
}

1976). Snowfalls are frequent from November through April. The mean temperature is $7.8^{\circ} \mathrm{C}$, ranging from $-6.4^{\circ} \mathrm{C}$ in January to $22.6^{\circ} \mathrm{C}$ in July.

\section{Methods}

Twelve 60 - by $60-\mathrm{m}$ (0.36-ha) study sites were selected: 10 on bentonite mine spoils established between 1952 and 1978 and 2 in adjacent, unmined vegetation. The study sites were grouped into 4 types by reclamation treatment and analyses of vegetative data: (1) old mine spoils, (2) reclaimed spoils, (3) semireclaimed spoils, and (4) sagebrush-grass rangeland. Five study sites were located on old unreclaimed mine spoils ( 12 to 28 yr old) constructed before reclamation laws were passed; these were steep and sparsely vegetated. Three study sites were on reclaimed mine spoils ( 5 to $12 \mathrm{yr}$ old) which had been countoured, covered with topsoil, and seeded with a mixture of wheatgrasses (Agropyron spp.) and yellow sweetclover (Melilotus officinalis). Two study sites were established on recently mined, semireclaimed bentonite mine spoils, both of which had been contoured and covered with topsoil in 1978. Rillscale (Atriplex suckleyi) was the most common plant on all bentonite spoils (Sieg et al. 1983). Two study sites were located on gently undulating, unmined big sagebrush-grass rangeland. Big sagebrush, followed by western wheatgrass (Agropyron smithii) and green needlegrass (Stipa viridula) were important plant species on sagebrush grasslands (Sieg et al. 1983).

Arthropod populations were sampled with metal-can pitfall traps, $15 \mathrm{~cm}$ deep and $15 \mathrm{~cm}$ in diameter. Twelve traps were buried flush with the soil surface on each site in a grid pattern with $15-\mathrm{m}$ spacing. The pitfall traps were opened every 3 weeks from April through October for 3 consecutive nights by placing a $2-$ to $4-\mathrm{cm}$ block under the edge of a wooden lid. The arthropods were collected, classified, and counted daily. Pitfall traps may influence the types of arthropods captured (Greenslade 1964, Nelson 1970, Baars 1979). However, pitfall traps have provided satisfactory density estimates for tenebrionids (Thomas and Sleeper 1977), carabids (Baars 1979), and diplopods, spiders, and orthopterans (Gist and Crossley 1973).

Plant canopy cover was estimated on the 12 sites during late spring, midsummer, and late summer of 1979 and 1980. Plant canopy cover was estimated by species in $150,20-$ by $50-\mathrm{cm}$ quadrats placed at $1-\mathrm{m}$ intervals along 3 permanent, $50-\mathrm{m}$ line transects on each site using methods modified from Daubenmire (1959). Canopy cover was visually estimated to fall into 1 of 7 cover classes: $0=$ less than $1 \%$ cover; $1=1-5 \% ; 2=5-25 \% ; 3=25-50 \% ; 4=$ $50-75 \% ; 5=75-95 \%$; and $6=95-100 \%$ cover. Plant nomenclature follows Nickerson et al. (1976).

Plant standing crop was estimated by harvesting aboveground portions of all plants except big sagebrush annually at estimated peak production (late July) on all sites. Plants were clipped at ground level in 10,20-by 50-cm quadrats on each of 3 permanent transects on each site. Plant species were separated in the field, oven dried in the laboratory at $60^{\circ} \mathrm{C}$ for $48 \mathrm{hr}$, and weighed.

One- and 2-way (incorporating both years) analyses of variance and Tukey's multiple comparison procedure (Kleinbaum and Kupper 1978) were used to compare arthropod numbers, plant canopy cover, and plant standing crop among site types. Bartlett's Box $F$ test was used to test for homogeneity of variances. Data with heterogeneous variances were $\log$ transformed. Student $t$-tests, Spearman's rank order correlation coefficients, and Kulcynski's similarity indices (Steel and Torrie 1980) were used to compare arthropod composition and means among site types and years. 
Table 1. Two-year average ( $\bar{X} \pm$ SE) captures of common arthropod familles on bentonite mine spolls and agebruah graselands near Alzada, Montana.'

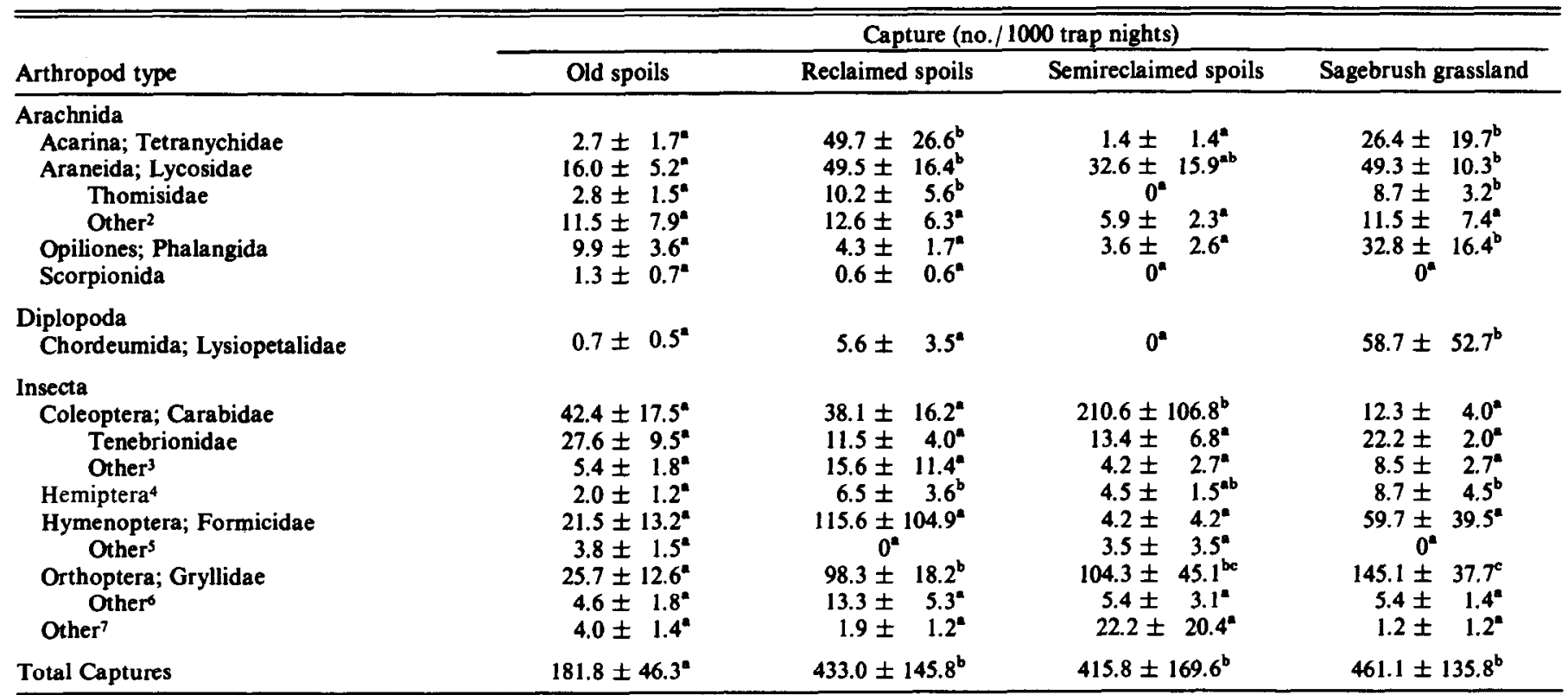

For each family, values with the same superscript were not significantly different $(P>0.1)$.

2Salticidae and unknown.

'Chrysomelidae, Coccinellidae, Curculionidae, Dermestidae, Histeridae, Scarabeide, Silphidae, unknown.

Lygaeidae, Pentatomidae, Miridae, Reduviidae, unknown.

'Scolidae, Sphecidae, unknown.

'Acrididae, Gryllacrididae.

'Lepidoptera and unknown.

Relationships between arthropod densities (dependent variable) and total canopy cover, cover of litter, bare ground, shrubs, and standing crop (independent variables) were evaluated by simple regression analyses (Hull and Nie 1981). Tests of significance were at $\alpha=0.05$ unless otherwise stated.

\section{Results}

\section{Arthropods}

Total arthropod captures substantially declined from 1,187 in 1979 to 530 in 1980 . However, the rank order of major arthropod groups for the 2 years was significantly correlated $\left(r_{\mathrm{s}}=0.89\right)$, indicating the relative contribution of various arthropod groups to the total arthropod population was similar in both years. Common arthropods included coleopterans, orthopterans, hymenopterans, and spiders. Ground beetles (Carabidae) and darkling beetles (Tenebrionidae) were the most common coleopterans, but a few specimens of 7 other families were also captured (Table 1). Crickets (Gryllidae) comprised the majority of the orthopterans; ants (Formicidae) were the most common hymenopterans. The Araneida group was dominated by wolf spiders (Lycosidae), followed by crab spiders (Thomisidae). Spider mites (Acarina; Tetranychidae), daddylonglegs (Opiliones; Phalangida), millipedes (Chordeumida; Lysiopetalidae), and various true bugs (Hemiptera) each made up less than $5 \%$ of the capture. Scorpions (Scorpionida) and Lepidoptera larvae made up less than $1 \%$ of the capture.

Total arthropod captures were lowest on old bentonite spoils, but similar among other sites (Table 1). Numbers of some families varied among site types. Daddylonglegs (Phalangida) and millipedes (Diplopoda) were captured in higher numbers on sagebrush grasslands than on mine spoils (Table 1). Captures of spider mites (Tetranychidae), wolf spiders (Lycosidae), jumping spiders (Thomisidae), and true bugs (Hemiptera) were generally higher on reclaimed bentonite mine spoils and unmined sagebrush grasslands than on other sites. Ground beetles (Carabidae) were the only family captured in higher numbers on semireclaimed spoils than on other sites. Ant captures showed a tendency (not statistical) towards highest numbers on reclaimed spoils. Darkling beetle (Tenebrionidae) captures were similar among site types. Cricket (Gryllidae) captures were lowest on old bentonite spoils and were lower on reclaimed spoils than on sagebrush grasslands. Overall, arthropod composition on reclaimed spoils was most similar to the composition on unmined sagebrush grasslands (Table 2).

Table 2. Similarity indices of ground-dwelling arthropod captures, comparing relative abundances on agebrush graselands with abundances on old, reclaimed, and semireclaimed bentonite mine spoils near Alzada, Montana.

\begin{tabular}{lccc}
\hline & \multicolumn{3}{c}{$\begin{array}{c}\text { Percent similarity to captures on } \\
\text { sagebrush grasslands }\end{array}$} \\
\cline { 2 - 4 } Arthropod & $\begin{array}{c}\text { Old } \\
\text { spoils }\end{array}$ & $\begin{array}{c}\text { Relclaimed } \\
\text { spoils }\end{array}$ & $\begin{array}{c}\text { Semireclaimed } \\
\text { spoils }\end{array}$ \\
\hline type & 19 & 69 & 10 \\
Acarina & 49 & 100 & 80 \\
Araneida; Lycosidae & 49 & 92 & 0 \\
$\quad$ Thomisidae & 46 & 23 & 20 \\
Opiliones; Phalangida & 2 & 17 & 0 \\
Diplopoda & 45 & 49 & 11 \\
Coleoptera; Carabidae & 92 & 52 & 59 \\
$\quad$ Tenebrionidae & 38 & 86 & 68 \\
Hemiptera & 53 & 68 & 13 \\
Hymenoptera; Formicidae & 30 & 81 & 84 \\
Orthoptera; Gryllidae & & & \\
\hline
\end{tabular}

\section{Vegetation}

Total plant canopy cover, cover of litter and shrubs, and total standing crop were all higher on sagebrush grasslands than on the bentonite spoils (Table 3). Plant canopy cover, litter cover, and standing crop were higher on reclaimed bentonite spoils than on old or semireclaimed mine spoils. The rank order of the canopy cover of plant species on the 4 site types was significantly correlated for the $2 \mathrm{yr}$, indicating that plant species composition on each site type did not change over years. 
Table 3. Two-year average vegetative characteriatics on bentonite mine spoils and sagebrush grasalands near Alzada, Montana.1

\begin{tabular}{|c|c|c|c|c|}
\hline \multirow[b]{3}{*}{$\begin{array}{l}\text { Total cover }(\%) \\
\text { Litter }(\%) \\
\text { Bareground }(\%) \\
\text { Shrub Cover }(\%) \\
\text { Standing Crop }(\mathrm{kg} / \mathrm{ha})\end{array}$} & \multicolumn{4}{|c|}{ Site Type } \\
\hline & Old spoils & Reclaimed spoils & Semireclaimed spoils & Sagebrush grasslands \\
\hline & $\begin{array}{r}3.3 \pm 0.6^{\circ} \\
4.3 \pm 0.6^{\circ} \\
92.3 \pm 0.8^{n} \\
0.3 \pm 0.1^{\circ} \\
55.6 \pm 24.9^{\circ}\end{array}$ & $\begin{array}{c}12.3 \pm 1.4^{b} \\
13.3 \pm 0.5^{b} \\
80.8 \pm 1.7^{a} \\
0.1 \pm 0.1^{a} \\
231.3 \pm 52.7^{\circ}\end{array}$ & $\begin{array}{c}3.2 \pm 0.9^{n} \\
2.3 \pm 0.4^{n} \\
93.7 \pm 1.0^{n} \\
0 \pm 0^{n} \\
91.3 \pm 33.3^{a}\end{array}$ & $\begin{array}{r}32.2 \pm \quad 2.1^{\mathrm{c}} \\
20.6 \pm 1.2^{\mathrm{c}} \\
52.7 \pm 3.2^{\mathrm{b}} \\
19.9 \pm 1.9^{\mathrm{b}} \\
428.4 \pm 123.2^{\mathrm{c}}\end{array}$ \\
\hline
\end{tabular}

'Means in each row followed by the same superscript were not significantly different $(P \geq 0.05)$.

Table 4. Significant correlation coeficients for numbers of various arthropods per site (dependent variable), regressed on habitat variablea (independent variables), for sagebrush graselands and bentonite mine spoils near Alzada, Montana.

\begin{tabular}{|c|c|c|c|c|c|}
\hline $\begin{array}{l}\text { Arthropod } \\
\text { Type }\end{array}$ & $\begin{array}{c}\text { Total } \\
\text { Cover }(\%)\end{array}$ & $\begin{array}{c}\text { Litter } \\
\text { Cover }(\%)\end{array}$ & $\begin{array}{l}\text { Bare ground } \\
(\%)\end{array}$ & $\begin{array}{c}\text { Shrub cover } \\
(\%)\end{array}$ & $\begin{array}{l}\text { Plant standing } \\
\text { crop }(\mathbf{k g} / \mathbf{h a})\end{array}$ \\
\hline Acarina; Tetranychidac & - & $0.36^{*}$ & - & - & $0.39 *$ \\
\hline Araneida; Lycosidae & $0.48^{* *}$ & $0.44 * *$ & $-0.50 * *$ & - & $0.54 * *$ \\
\hline Thomisidae & $0.38^{*}$ & - & $-0.36^{*}$ & - & $0.40^{*}$ \\
\hline Opiliones; Phalangida & $0.56 *$ & $0.42 *$ & $-0.56^{* *}$ & $0.66^{* *}$ & $0.50^{* *}$ \\
\hline Chordeumida; Lysiopetalidae & $0.58 * *$ & - & $-0.52 * *$ & $0.61^{* *}$ & $0.59 * *$ \\
\hline Coleoptera; Carabidae & - & - & - & - & - \\
\hline Tenebrionidae & - & - & - & - & - \\
\hline Hymenoptera; Formicidae & - & - & - & - & $0.48 * *$ \\
\hline Orthoptera; Gryllidae & $0.59 * *$ & $0.51 * *$ & $-0.65 * *$ & $0.38^{*}$ & $0.68 * *$ \\
\hline Total arthropods & $0.47 * *$ & - & $-0.46^{* *}$ & - & $0.66^{* *}$ \\
\hline
\end{tabular}

Significant at $P \leq 0.05$.

* Significant at $P \leq 0.01$.

'Lycosidae and Thomisidae were also positively associated with captures of Acarina $(r=0.61$ and 0.89 , respectively; $\mathrm{P}<0.001)$.

\section{Arthropod-Vegetation Relationships}

Plant standing crop was the parameter most associated $(P<0.01)$ with total arthropod numbers on the study sites; other variables related to total arthropods were total plant canopy cover and bare ground (Table 4). Phalangid, diplopod, and gryllid numbers were positively associated with shrub cover. These 3 families were also associated with at least 3 of the following variables: total plant canopy cover, litter cover, bare ground, and plant standing crop. Tetranychid abundance was associated with litter cover and plant standing crop. Abundance of predatory spiders, the lycosids and thomisids, was associated with total plant cover, bare ground, plant standing crop, and with captures of Acarina (a potential prey species). Lycosid numbers were also positively associated with litter cover. Numbers of formicids was positively associated with only plant standing crop. Abundance of carabids and tenebrionids was not significantly associated with any of the measured habitat variables.

\section{Discussion}

Bentonite mining in southeastern Montana resulted in habitat conversions that apparently impacted arthropods captured in pit traps. The most significant impacts were on old bentonite spoils, where after nearly $30 \mathrm{yr}$, numbers of 7 arthropod groups remained lower than on unmined sagebrush grasslands. In spite of similar vegetative characteristics on old and semireclaimed spoils, total arthropod captures and numbers of carabids and gryllids were higher on semireclaimed spoils than on old spoils, indicating that the presence of topsoil may encourage colonization by some arthropods. Early reclamation efforts restored captures of arachnids (except phalangids), Coleoptera, Hemiptera, and Formicidae to levels similar to those on unmined sagebrush grasslands. Reclaimed spoils failed to support comparable captures of arthropods that were positively associated with shrub cover: phalangids, diplopods, and gryllids.

Plant standing crop was the parameter most associated with total arthropods captured in pit traps. Insect densities on a shortgrass range in Texas were correlated with herbage production, with peak numbers occurring in years with greater plant production (Huddleston et al. 1975). Litter cover and shrub cover were other parameters related to arthropod captures in our study. Majer et al. (1982) stressed the importance of an adequate litter layer and diverse vegetation for ants and other invertebrates to return to mine spoils, and Ditsworth et al. (1982) related shrub cover to captures of some arthropods. Dense vegetation and litter cover provide moist microhabitats preferred by arthropods such as spider mites (Borror and DeLong 1971), prey for predatory spiders, and protection for cryptozoic arthropods such as daddylonglegs and crickets.

Habitat variables measured in this study explained only a portion of the variability in arthropod captures; captures of carabids and tenebrionids were not associated with any of the measured variables. Microarthoprod populations, arthropod vagility, and soil water contents may influence repopulation of mine spoils by some arthropods. The distribution of predatory spiders such as lycosids may be influenced by the presence of prey species. Ground beetles are highly mobile arthropods which have been reported to quickly colonize new mine spoils (Neumann 1973). Daddylonglegs and ants are less vagile, and are therefore often slow to colonize disturbed sites (Uetz et al. 1979). Populations of 6 species of tenebrionids did not respond to radical changes in plant productivity, but were linked to soil moisture conditions (Thomas 1979). Further research is required to precisely identify variables that most highly influence arthropod repopulation of bentonite mine spoils.

\section{Literature Cited}

Banrs, M.A. 1979. Catches in pitfall traps in relation to mean densities of carabid beetles. Oecologia 41:25-46.

Borror, D.J., and D.J. DeLong. 1971. An introduction to the study of insects, 3rd Edition. Holt, Rinehart and Winston, Inc., New York.

Daubenmire, R. 1959. A canopy-cover method of vegetation analysis. Northwest Sci. 33:43-64. 
Ditsworth, T.M., S.M. Butt, J.R. Beley, C.D. Johnson, and R.P. Balda. 1982. Arthropods, plants, and transmission lines in Arizona: community dynamics during secondary succession in a pinyon-juniper woodland. Southwest. Natur. 27:167-181.

Ettershank, G., N.Z. Elkins, P.F. Santos, W.G. Whitford, and E.F. Aldon. 1978. The use of termites and other soil fauna to develop soils on strip mine spoils. USDA Forest Serv. Res. Note RM-361. Rocky Mountain Forest and Range Exp. Sta., Fort Collins, Colo.

Gist, C.A., and D.A. Crossley. 1973. A method for quantifying pit-fall trapping. Environ. Entomol. 3:951-952.

Greenslade, P.J.M. 1964. Pitfall trapping as a method for studying populations of Carabidae (Coleoptera). J. Animal Ecol. 33:301-310.

Huddleston, E.W., R.A. Shaw, and M.V. Riggs. 1975. Insect population dynamics studies of the Pantex site, 1972. U.S. International Biological Program, Grassland Biome, Tech. Rep. No. 280. Nat. Res. Ecol. Lab. Colorado State Univ., Fort Collins.

Hull, C.H., and N.H. Nie. 1981. SPSS Update 7-9, McGraw-Hill Book Co., New Yok.

Kleinbaum, D.G., and L.L. Kupper. 1978. Applied regression analysis and other multivariable methods. Duxburg Press, North Scituate, Mass.

MacCracken, J.G., D.W. Uresk, R.M. Hansen. 1983. Plant community variability on a small area in southeastern Montana. Great Basin Natur. 43:660-668.

Majer, J.D., M. Sartori, R. Stone, and W.S. Perriman. 1982. Recolonization by ants and other invertebrates in rehabilitated mineral sand mines near Eneabba, Western Australia. Reclamation and Rev. Res. 1:63-81.

Majer, J.D., J.E. Day, E.D. Kabay, and W.S. Perriman. 1984. Recolonization by ants in bauxite mines rehabilitated by a number of different methods. J. Applied Ecol. 21:355-375.
National Oceanic and Atmospheric Adminiatration. 1976. Climate of Colony, Wyoming. Climatography of the United States No. 20. Asheville, N.C.

Nelson, D.H. 1970. Population dynamics in the carabid beetle: Pasimachus punctulatus. Southwest. Natur. 15:55-69.

Neumann, U. 1973. Succession of soil fauna in a forested spoil bank of the browncoal mining district of Cologne. p. 335-348. In. Hutnik, R. J., and G. Davis (eds.) Ecology and reclamation of devastated land, Vol. 2. Gordon and Breach, New York.

Nickerson, M.F., G.E. Brink, and C. Feddema. 1976. Principal plants of the central and southern Rocky Mountains. Names and symbols. USDA Forest Serv. Gen. Tech. Rep. RM-20. Rocky Mountain Forest and Range Exp. Sta., Fort Collins, Colo.

Sies, C.H., D.W. Ureak, and R.M. Hansen. 1983. Plant-soil relationships on bentonite mine spoils and sagebrush-grasslands in the northern High Plains. J. Range Manage. 36:289-294.

Smith, V.G. 1928. Animal communities of a deciduous forest succession. Ecology 9:479-500.

Steel, R.G., and J.H. Torrie. 1980. Principles and procedures of statistics, 2nd Edition. McGraw-Hill Book Co., Inc., New York, N.Y.

Thomas, B., Jr. 1979. Patterns in the abundance of some tenebrionid beetles in the Mojave desert. Environ. Entomol. 8:568-574.

Thomas, B., Jr., and E.L. Sleeper. 1977. The use of pitfall traps for estimating the abundance of arthropods, with specific reference to the Tenebrionidae (Coleoptera). Ann. Entomol. Soc. Amer. 70:242-248.

Uetz, G.W., K.L. Van der Lan, G.F. Summers, P.A.K. Gibson, and L.L. Getz. 1979. The effects of flooding on floodplain arthropod distribution, abundance and community structure. Amer. Midland Natur. 101:287-299. 